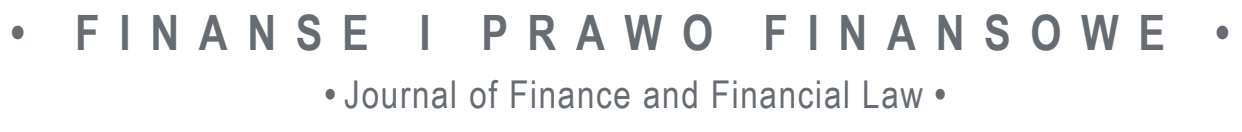

Czerwiec/June 2020 • vol. 2(26): 63-82

https://doi.org/10.18778/2391-6478.2.26.05

\title{
SKUTECZNOŚĆ PRAWNA OCHRONY TZW. „FRANKOWICZÓW” W KONTEKŚCIE TERMINÓW PRZEDAWNIENIA
}

\author{
Aleksandra Nadolska \\ WSAiB w Gdyni \\ ORCID: https://orcid.org/0000-0003-4903-8336
}

\begin{abstract}
Streszczenie
W Polsce nie wykształciła się jednolita linia orzecznicza, tak co do przesłanek i podstaw unieważnienia umowy kredytu, jak i co do uznania niektórych tylko warunków umownych za nieuczciwe, a w efekcie tego - również co do stosowania terminów przedawnienia wobec żądania zwrotu świadczenia wypłaconego na podstawie uznanej za abuzywną klauzuli bądź nieważnej czynności prawnej. Sytuacji tej nie zmienił wyrok TSUE z 3.10.2019 r. (C-260/18 Dziubak vs. Raiffeisen). Pożądane i konieczne jest tymczasem, aby krajowe sądy zaczęły rozstrzygać sprawy tzw. "frankowe” $w$ duchu regulacji unijnych, bo to $w$ ich ramach przyjęto ideę pełnej ochrony prawnej konsumenta, zasadniczo wedle której realizacja roszczenia restytucyjnego nie może być uzależniona od terminu przedawnienia.

Celem artykułu jest udzielenie odpowiedzi na pytanie: czy skutek restytucyjny obejmuje - obok dawnego stanu prawnego - przywrócenie stanu materialnego kontrahentów? Udzielenie odpowiedzi na to pytanie jest niezbędne dla ustalenia, czy sądowe uznanie warunków umowy za nieuczciwe może zostać ograniczone co do rodzaju skutku.

Powyższe legło u podstaw sformułowania następującej tezy badawczej: ustalenie w postępowaniu sądowym nieuczciwości warunku umownego zawsze będzie miało charakter i skutek ex tunc wobec uprawnień majątkowych oraz niemajątkowych, i to bez względu na to, czy rozstrzygnięcie w tym przedmiocie jest konstytutywne czy deklaratoryjne.

Przedstawiona materia zdeterminowała układ i treść artykułu, w którym wieloaspektowo omówiono problematykę terminów przedawnienia (ujętą w pytaniach prejudycjalnych oraz orzecznictwie TSUE), przedstawiono podział orzeczeń na konstytutywne i deklaratoryjne, a także wyjaśniono istotę i funkcję materialnych terminów przedawnienia.
\end{abstract}

Słowa kluczowe: przedawnienie, skutek restytucyjny, orzeczenie konstytutywne/deklaratoryjne, klauzula abuzywna, unieważnienie umowy kredytu.

JEL Class: K12, K15, D18, E44. 


\section{WSTĘP}

Instytucja przedawnienia roszczenia ma ogromne znaczenie praktyczne w sprawach tzw. „frankowiczów”, które dotyczą kredytów (indeksowanych do CHF lub denominowanych w CHF) wieloletnich, zaciąganych na cele mieszkaniowe i zabezpieczonych hipotecznie. Sądy polskie dopiero od niedawna uświadamiają sobie europejski wymiar tego problemu, co spowodowało, że w wielu prawomocnych już rozstrzygnięciach przesądzono, iż roszczenie obejmujące zwrot świadczenia nienależnego wypłaconego na podstawie klauzul abuzywnych uległo przedawnieniu. W konsekwencji pojawiło się orzecznictwo mało kompatybilne z prawem unijnym, opartym na idei pełnej ochrony prawnej konsumenta w stosunkach zawieranych z przedsiębiorcą (bankiem). Spowodowało to konieczność podjęcia w dyskursie naukowym rzeczonej kwestii, zwłaszcza, że do tej pory w ogóle nie zostało wyjaśnione (ani w judykaturze, ani w doktrynie prawa) jak należy wykładać krajowe przepisy o terminach przedawnienia w kontekście spraw frankowych i czy (a jeśli tak, to jaki) wpływ na tę intepretację ma charakter wydawanego wyroku. Jest to o tyle istotne, że obecnie coraz więcej spraw tego rodzaju jest poddawanych pod rozstrzygnięcie sądów cywilnych, które w większości bazują na dotychczasowej linii orzeczniczej (bez względu na to, czy jest ona słuszna, czy nie). A przecież wyniki takich postępowań bezpośrednio wpływają nie tylko na sytuację stron (i/lub poręczycieli), ale też sektor bankowy i całą gospodarkę. Wobec tego, wypełniając tę lukę, wszystkie powyższe zagadnienia zostały poddane szczegółowej i wieloaspektowej analizie w tym artykule. Z przedstawionych w jego treści rozważań wynika, że skutek restytucyjny (wobec stwierdzenia istnienia nieuczciwego warunku umownego) obejmuje zarówno przywrócenie dawnego stanu prawnego, jak i stanu materialnego stron umowy kredytu bankowego, co determinuje konieczność zasądzenia przez sąd na każde (zasadne) żądanie powoda/powódki zapłaty świadczenia nienależnego z tego tytułu (oczywiście jeśli tylko nie upłynął termin 6/10 lat liczony od samego stwierdzenia abuzywności danej klauzuli).

\section{ZAKRES PRAWNEJ OCHRONY KONSUMENTA}

Przepisy art. $385^{1}-385^{3}$ k.c. zostały wprowadzone do kodeksu cywilnego [Ustawa z 23 kwietnia 1964 r., Dz.U. 2019, poz. 1145 ze zm.] ustawą z 2 marca 2000 r. o ochronie niektórych praw konsumentów oraz o odpowiedzialności za szkodę wyrządzoną przez produkt niebezpieczny [Dz.U.2012, poz. 1225 ze zm.]. Nowelizacja dokonana ww. aktem wynikała z konieczności dostosowania prawa polskiego do wymagań dyrektywy Rady 93/13/EWG z 5 kwietnia 1993 r. w sprawie nieuczciwych warunków w umowach konsumenckich [Dz.U. UE.L. 1993.95.29 
z 21 kwietnia 1993 r.], która bazuje na modelu minimalnej harmonizacji ${ }^{1}$. Dyrektywa ta jest oparta na zasadach. Zapewnia ona konsumentom ochronę przed nieuczciwymi warunkami we wszelkiego rodzaju umowach zawartych z przedsiębiorcami. $\mathrm{Z}$ tego względu odgrywa kluczową rolę w zapewnieniu uczciwości na rynku wewnętrznym.

Ścisły związek art. $385^{1}-385^{3}$ k.c. z regulacjami dyrektywy 93/13/EWG wiąże się z koniecznością uwzględnienia przy ich wykładni i stosowaniu przepisów prawa UE (zwłaszcza art. 3, art. 4, art. 6 i art. 7 oraz załączników do niej), jak też dotyczącego go znacznego dorobku orzeczniczego Trybunału Sprawiedliwości Unii Europejskiej [por. wyrok Sądu Najwyższego z 3 lutego 2006 r., I CK 297/05]. Trzeba zaznaczyć przy tym, że orzecznictwo TSUE jest traktowane jako jedno z zasadniczych źródeł prawa unijnego. Niezwykle silna pozycja Trybunału w strukturach unijnych wiąże się właśnie z quasi-prawotwórczą działalnością odzwierciedlającą pragmatyzm systemu anglosaskiego.

Powyższe oczywistości są znane, choć bagatelizowane przez polskie sądy cywilne, które od kilku lat zmagają się z rozwiązywaniem sporów klientów usług finansowych z bankami, w szczególności wynikających z umów kredytów tzw. „frankowych"2. Nieudolność tych zabiegów jest najwyraźniej widoczna przez pryzmat braku wykształcenia na przestrzeni ostatnich kilku lat jednolitej linii orzeczniczej $^{3}$, tak co do przesłanek i podstaw unieważnienia umowy kredytu w całości bądź części (np. co do aneksu, na podstawie którego wprowadzono do stosunku zobowiązaniowego mechanizm waloryzacji), jak i co do uznania niektórych tylko warunków umownych za nieuczciwe, a w efekcie tego - również co do stosowania terminów przedawnienia wobec żądania zwrotu świadczenia wypłaconego stronie na podstawie uznanej za abuzywną klauzuli bądź nieważnej czynności prawnej ${ }^{4}$. Zasadniczo sytuacji tej nie zmienił wyrok TSUE z 3 października

${ }^{1}$ Harmonizacja systemów prawnych polega na wypracowaniu i wprowadzaniu wspólnych rozwiązań i standardów, które służą ułatwianiu transakcji dokonywanych na terytorium kilku państw. Harmonizacja nie jest zjawiskiem homogenicznym - może występować na różnych poziomach. W jej ramach wyróżnia się harmonizację maksymalną i harmonizację minimalną. Ta druga wprowadza minimalne wymogi, które mogą zostać zaostrzone w ustawodawstwie krajowym.

${ }^{2}$ Chodzi tu głównie o umowy kredytu denominowanego w CHF oraz indeksowanego do CHF.

${ }^{3}$ Por. Jabłoński i Koźmiński [2018]; a także Grebieniow i Osajda [2019].

${ }^{4}$ Sąd Najwyższy w wyroku z 29 października 2019 r., IV CSK 309/18, wskazał, że czym innym jest ,uznanie umowy za nieważną”, a czym innym ,unieważnienie umowy, która bez klauzuli niedozwolonej nie może dalej funkcjonować w obrocie prawnym, zwłaszcza ze względu na brak (odpadnięcie) któregoś z koniecznych składników (essentialia negotii) umowy nazwanej kredytu bankowego". Wprawdzie TSUE przyjął, że wymaganiom wynikającym z art. 6 dyrektywy 93/13/EWG czyni zadość sankcja nieważności bezwzględnej (zob. wyroki z 26 kwietnia 2012 r., C-472/10 Nemzeti Fogyasztóvédelmi Hatóság v. Invitel Távközlési Zrt, pkt 40 oraz z 30 maja 2013 r., C-397/11 Erika Jörös v. Aegon Magyarország Hitel Zrt., pkt 43), jednak państwa członkowskie mogą stosować również inne sankcje. Wykładnia krajowych regulacji w tej części sprowadza się właśnie do przyjęcia, że jeżeli po wyeliminowaniu nieskutecznych klauzul umowa w całości nie 
2019 r. wydany w sprawie C-260/18 Dziubak vs. Raiffeisen [http://eur-lex.europa.eu/, dostęp 12.03.2020], skoro niektóre sądy stoją jeszcze na stanowisku, że może on mieć zastosowanie wyłącznie do kredytów indeksowanych do CHF (zapominając, że wykładnia Trybunału dotyczy regulacji dyrektywy 93/13/EWE, a nie przepisów polskiego prawa bankowego, i określa, w jaki sposób dany przepis powinien być lub powinien był być rozumiany i stosowany od chwili jego wejścia w życie).

Pożądane i konieczne jest tymczasem, aby krajowe sądy zaczęły rozstrzyganie spraw tzw. ,frankowych” od analizy ww. aktu unijnego w sprawie nieuczciwych warunków w umowach konsumenckich oraz przeglądu orzecznictwa TSUE do niego wydanego, bo stanowi ono ogromny zasób zasad, które winny być stosowane niezależnie od specyfiki prawnych uwarunkowań państw członkowskich $^{5}$. Jedną z nich jest reguła, w myśl której ochrona prawna konsumentów leży w „interesie publicznym”, stąd jej skuteczność musi sprowadzać się do przywrócenia sytuacji prawnej i faktycznej klienta usług finansowych, w jakiej znajdowałby się w braku niedozwolonego zapisu. To z kolei oznacza konieczność cofnięcia stron sporu w czasie do momentu sprzed podpisania umowy kredytu. Przeszkodą ku temu nie mogą być krajowe przepisy materialnoprawne dotyczące terminów przedawnienia, jako że w sprawach tzw. „frankowiczów” nie chodzi stricte o dochodzenie roszczenia pieniężnego, lecz o przywrócenie równowagi kontraktowej stron (także w aspekcie materialnym) i zniechęcenie przedsiębiorcy na przyszłość do posługiwania się wzorcem umowy standaryzowanej obejmującej nieuczciwe warunki.

\section{TERMINY PRZEDAWNIENIA JAKO PRZEDMIOT PYTAŃ PREJUDYCJALNYCH POLSKIEGO SĄDU}

Sąd Okręgowy w Gdańsku postanowieniem z 30 grudnia 2019 r., XV C 458/18 [niepubl.], zadał Trybunałowi Sprawiedliwości Unii Europejskiej pięć pytań prejudycjalnych. Treść jednego z nich jest następująca: Czy brak obowiązywania

może wiązać stron bez uzgodnienia najważniejszych ich obowiązków, to należy rozstrzygnąć o jej nieważności (czego jednak nie należy utożsamiać z orzeczeniem wydanym na podstawie art. 189 k.p.c. bądź art. 58 k.c. czy art. 388 k.c.).

${ }^{5}$ Częstym problemem sądów polskich jest dążenie do zastosowania orzeczenia TSUE literalnie, wprost, dopasowując go do układu krajowych instytucji prawnych, co obiektywnie jest po prostu niemożliwe i opiera się na błędzie metodologicznym. Trybunał operuje bowiem zwrotami i pojęciami, które mają różne znaczenie w porządkach prawnych państw członkowskich. Zdarza się też, że odwołuje się do instytucji nieznanych w tych porządkach prawnych. Nie chodzi jednak o to, żeby orzecznictwo krajowe było spójne z unijnym w zakresie definicyjnym, ale o to, by stosowano w jego ramach zasady i mechanizmy, na których opierają się kluczowe paradygmaty wspólnej w UE ochrony konsumenckiej. 
umowy, o którym mowa w art. 6 ust. 1 dyrektywy Rady 93/13/EWG z dnia 5 kwietnia 1993 r. $w$ sprawie nieuczciwych warunków $w$ umowach konsumenckich (Dz.U.L.95, s. 29), stanowiący rezultat wyłaczenia nieuczciwych warunków umownych, określonych $w$ art. 2 lit. a) $w$ zw. z art. 3 dyrektywy, należy rozumieć $w$ ten sposób, że jest to sankcja, która może nastapić jako rezultat konstytutywnego orzeczenia sądu wydanego na wyraźne żądanie konsumenta z konsekwencjami od momentu zawarcia umowy, tj. ex tunc, a roszczenie restytucyjne konsumenta i przedsiębiorcy staja się wymagalne wraz z uprawomocnieniem się wyroku?

W uzasadnieniu do tego pytania Sąd Okręgowy wskazał, że krajowy ustawodawca, wbrew motywowi dwudziestemu pierwszemu preambuły oraz artykułowi 6 ust 1. dyrektywy 93/13/EWG nie implementował w pełni do polskiego porządku prawnego celów tego aktu prawnego, wyrażających się w konieczności zapewnienia, aby umowa zawarta pomiędzy konsumentem a sprzedawcą (dostawcą) nie obowiązywała, jeżeli nie jest to możliwe po wyłączeniu z niej nieuczciwych warunków. Powołując się na treść art. $385^{1} \S 2$ k.c. (,jeżeli postanowienie umowne zgodnie z $\S 1$ nie wiąże konsumenta, strony są związane umową w pozostałym zakresie") Sąd ten uznał, że ustawodawca krajowy pominął wyrażone w art. 6 ust. 1 dyrektywy unijnej zastrzeżenie ,o ile jest to możliwe po wyłączeniu nieuczciwych warunków". Sąd orzekający stwierdził następnie, że w sądach polskich kształtuje się linia orzecznicza, zgodnie z którą w sytuacji, gdy obowiązywanie umowy nie jest możliwe po eliminacji nieuczciwych postanowień, stwierdza się jej nieważność na podstawie art. $58 \S 3 \mathrm{w}$ zW. z $§ 1$ k.c. [por. np. wyrok Sądu Okręgowego w Warszawie z 15 marca 2019 r., XXV C 2/19]. Podkreślił przy tym, że powołana regulacja doczekała się na gruncie innych stanów faktycznych utrwalonej wykładni, wedle której nieważność czynności prawnej oznacza, że nie wywołuje ona jakichkolwiek skutków prawnych w niej wyrażonych, co następuje z mocy prawa, niezależnie od woli stron, a wyrok stwierdzający nieważność czynności prawnej ma charakter deklaratoryjny. Nadto Sąd Okręgowy uznał, że w świetle k.c. dopuszczalne jest unieważnienie umowy z mocą wsteczną (tj. od dnia zawarcia) na podstawie konstytutywnego orzeczenia sądu wydanego na wniosek strony umowy w ramach instytucji wyzysku uregulowanej w art. 388 k.c. Zaznaczył jednocześnie, że w orzecznictwie sądów krajowych dotyczących umów kredytowych indeksowanych do waluty obcej raczej nie spotyka się sięgania w drodze analogii do art. 388 k.c.

W ocenie Sądu Okręgowego w Gdańsku dotychczasowe orzecznictwo TSUE na tle wykładni artykułu 6. ust. 1 dyrektywy [m.in. sprawa C-26/13 czy C-260/18, a także sprawy połączone C-154/15, C-307/15 i C-308/15] wskazuje jednak na inne niż prezentowane w orzecznictwie polskim, cechy sankcji braku dalszego obowiązywania umowy, gdy nie jest to możliwe po 
usunięciu z jej treści postanowień niedozwolonych. Oznaczać to może, że unieważnienie umowy wobec eliminacji warunków niedozwolonych następuje z mocy konstytutywnego orzeczenia sądu, a nie z mocy samego prawa i to na żądanie tylko jednej strony umowy, czyli konsumenta, prowadząc do powstania po jego stronie roszczenia o zwrot niesłusznie nabytych przez przedsiębiorcę jego kosztem korzyści. Sąd krajowy na gruncie przytoczonych orzeczeń wyraził wobec tego wątpliwości, czy tak właśnie należy rozumieć sankcję braku obowiązywania umowy, co ma istotne znaczenie dla dokonania w postępowaniu głównym interpretacji prawa krajowego w zgodzie z celem dyrektywy. Ustalenie charakteru tej sankcji jest bowiem niezbędne dla oceny daty wymagalności zgłoszonych przez powodów roszczeń restytucyjnych oraz zasadności podniesionego przez pozwanego zarzutu przedawnienia. W dalszej kolejności może również okazać się ważna dla oceny tego, czy unieważnienie umowy w ogóle leży w interesie konsumenta.

Jakkolwiek zadane przez Sąd Okręgowy ww. pytanie prejudycjalne zostało skonstruowane w sposób budzący poważne wątpliwości pod względem logicznym (abstrahując już od tego, że pewne jego elementy zostały już przesądzone - np. to, że niewiążący charakter warunków umowy, które zostały uznane za nieuczciwe, stanowi fundamentalną zasadę porządku publicznego obowiązującą z mocy prawa [Zawiadomienie Komisji Europejskiej, pkt. 5.2.2]), o tyle rację ma ten Sąd wskazując, że kwestia przedawnienia ma ogromne znaczenie praktyczne w sprawach tzw. „frankowiczów”. W szczególności za sprawą przepisów art. 6 ust. 1, które stanowią, że nieuczciwe warunki umowne nie mają wiążącego charakteru, w dyrektywie 93/13/EWG dąży się do zapewnienia rzeczywistej równowagi [np. sprawy: C-421/14 Banco Primus, pkt 41; C-169/14 Sánchez Morcillo i Abril Garcia, pkt 23; połączone C-154/15, C-307/15 i C-308/15 Gutiérrez Naranjo i in., pkt 53 i 55] między kontrahentami poprzez usunięcie asymetrii wynikającej z nieuczciwych warunków umownych [sprawy połączone C-96/16 i C-94/17 Banco Santander Escobedo Cortés, pkt 69], aby zrekompensować konsumentom fakt, że znajdują się w gorszym położeniu [np. wyrok w sprawie C-169/14 Sánchez Morcillo i Abril García, pkt 22 oraz orzecznictwo przywołane w tym wyroku]. Przy czym rzeczywista równowaga dotyczy zarówno aspektu prawnego, jak i ekonomicznego (materialnego) konsumenta. Chodzi tu również o wywarcie zniechęcającego skutku wobec przedsiębiorcy poprzez zwyczajne i proste niestosowanie nieuczciwych warunków wobec konsumentów na przyszłość.

Na uboczu tego odnotować można jedynie, że odpowiedź na przytoczone pytanie Sądu Okręgowego w Gdańsku najprawdopodobniej nie wniesie nic nowego do dyskusji na temat zasad stosowania terminów przedawnienia w sprawach tzw. „frankowiczów”. Przede wszystkim dlatego, że Trybunał już wielokrotnie wypowiadał się na temat skutków ex tunc ustalenia niewiążącego charakteru warunków 
umownych, o czym szerzej poniżej. Ponadto, jak już zostało to zaakcentowane we wprowadzeniu, TSUE nie dokonuje wykładni prawa krajowego, w związku z czym nie jest uprawniony do kwalifikacji charakteru orzeczenia sądu polskiego stwierdzającego abuzywność klauzuli lub unieważniającego umowę w całości lub części na mocy art. $385^{1}$ k.c. i nast. Poza tym pamiętać trzeba, że nie o metodę (rodzaj rozstrzygnięcia) ${ }^{6}$, ale o cel tu chodzi, a dokładnie - by zapewnić konsumentowi (polskiemu, niemieckiemu, włoskiemu czy francuskiemu) pełną i skuteczną ochronę, do której dąży dyrektywa 93/13/EWG ${ }^{7}$.

\section{INSTYTUCJA PRZEDAWNIENIA W DOTYCHCZASOWYM ORZECZNICTWIE TRYBUNAŁU SPRAWIEDLIWOŚCI UNII EUROPEJSKIEJ}

Trybunał Sprawiedliwości Unii Europejskiej zasadniczo uznaje, że „rozsądne terminy" przedawnienia są dopuszczalne w interesie pewności prawa, na przykład w odniesieniu do roszczeń o zwrot kwot nienależnie zapłaconych na podstawie nieuczciwych warunków umownych [sprawy połączone C-154/15, C-307/15 i C-308/15 Gutiérrez Naranjo, pkt 6983. Wyjaśnić trzeba jednak, że w świetle interpretacji TSUE owe terminy odnoszą się do zasad proceduralnych wnoszenia środków ochrony prawnej [por. wyroki: z 16 grudnia 1976 r., 33/76 Rewe-Zentralfinanz $i$ Rewe-Zentral, pkt 5; z 10 lipca 1997 r., C-261/95 Palmisani, pkt 28; z 12 lutego 2008 r., C-2/06 Kempter, pkt 58], dlatego opatrzone są rygorem prekluzji (prekluzja jest zaś czym innym niż przedawnienie). Trybunał podejmował bowiem kwestię przedawnienia jedynie w kontekście ustanowienia rozsądnej długości terminu na wniesienie sprawy do sądu, po upłynięciu którego traci się możliwość wniesienia powództwa w zakresie, w jakim ustanowienie tego terminu stanowi stosowanie podstawowej zasady pewności prawnej. Trybunał wyraźnie zastrzegł przy tym, że warunki takiej ochrony nie mogą być mniej korzystne od warunków odnoszących się do podobnych postępowań o charakterze krajowym.

\footnotetext{
${ }^{6}$ Pojęcie nieuczciwych warunków umownych, które nie są wiążące dla konsumentów, można przełożyć na różne pojęcia prawne na poziomie krajowym pod warunkiem uzyskania ochrony, do której dąży się w dyrektywie 93/13/EWG. Wydaje się jednak, że zamierzoną ochronę najskuteczniej zapewniłaby nieważność nieuczciwych warunków umownych (tak orzekł TSUE w sprawach połączonych C-154/15, C-307/15 i C-308/15 Gutiérrez Naranjo, pkt 61).

${ }^{7}$ Wedle Autorki trafniejsze są pytania prejudycjalne $\mathrm{nr}$ 1) zadane przez Tribunalul Specializat Mureş w Rumunii w sprawach C-698/18 i C-699/18, w ramach których wyraźnie oddzielono niepodlegające przedawnieniu roszczenie o stwierdzenie nieuczciwego charakteru warunków umownych oraz podlegające przedawnieniu roszczenie zmierzające do wyeliminowania skutków wszystkich zobowiązań powstałych i wykonanych na podstawie nieuczciwego warunku. Szerzej o nich poniżej.

${ }^{8}$ Prawo hiszpańskie nie przewiduje jednak terminu przedawnienia w odniesieniu do tego typu roszczeń.
} 
Wyjaśnił jednocześnie, że terminy procesowe ${ }^{9}$ nie mogą być tak sformułowane, aby praktycznie uniemożliwiać lub nadmiernie utrudniać uzyskanie naprawienia szkody (zwrotu świadczenia nienależnego w przypadku tzw. „frankowiczów”).

Trybunał Sprawiedliwości Unii Europejskiej nie orzekł dotychczas, jaki termin przedawnienia (czy raczej prekluzji, bo analiza stanowiska Trybunału dowodzi, że mowa w nim o prekluzji; TSUE często utożsamia obie instytucje, posługując się nimi zamiennie, co w prawie polskim jest nie do przyjęcia) byłby rozsądny w tym zakresie, ani kiedy zaczyna się bieg takiego terminu. Do Trybunału już 7 listopada 2018 r. wpłynął jednak wniosek o przedstawienie wytycznych w tej drugiej kwestii (por. sprawy C-698/18 SC Raiffeisen Bank S.A. ${ }^{10}$ i C-699/18 BRD Groupe Société Générale S.A. ${ }^{11}$ - w toku na 8 czerwca 2020 r.). W mojej

${ }^{9}$ Termin procesowy do wniesienia pozwu o zapłatę odszkodowania nie jest znany polskiemu prawu cywilnemu. Dlatego należy raczej analizować ten wywód TSUE pod kątem prekluzji i/lub przedawnienia.

${ }^{10}$ Pytania prejudycjalne brzmią następująco: 1) Czy przepisy dyrektywy Rady 93/13/EWG w sprawie nieuczciwych warunków w umowach konsumenckich, w szczególności motywy 12, 21 i 23 , art. 2 lit. b), art. 6 ust. 1, art. 7 ust. 2 i art. 8, zgodnie z zasadą autonomii proceduralnej oraz równocześnie zasadami równoważności i skuteczności, zezwalają na obowiązywanie instrumentów prawnych obejmujących zwykłe roszczenie, niepodlegające przedawnieniu, mające na celu stwierdzenie nieuczciwego charakteru niektórych warunków ujętych $\mathrm{w}$ umowach zawieranych $\mathrm{z}$ konsumentami, oraz zwykłe roszczenie o charakterze osobistym i majątkowym, podlegające przedawnieniu, zmierzające do realizacji celu dyrektywy, jakim jest wyeliminowanie skutków wszystkich zobowiązań powstałych i wykonanych na podstawie warunku, którego nieuczciwy charakter został stwierdzony wobec konsumenta?; 2) Czy przepisy dyrektywy Rady 93/13/EWG w sprawie nieuczciwych warunków w umowach konsumenckich, w szczególności motywy 12, 21 i 23, art. 2 lit. b), art. 6 ust. 1 , art. 7 ust. 2 i art. 8, zgodnie z zasadą autonomii proceduralnej oraz równocześnie zasadami równoważności i skuteczności, zezwalają na obowiązywanie instrumentów prawnych obejmujących zwykłe roszczenie, niepodlegające przedawnieniu, mające na celu stwierdzenie nieuczciwego charakteru niektórych warunków ujętych w umowach zawieranych z konsumentami, oraz zwykłe roszczenie o charakterze osobistym i majątkowym, podlegające przedawnieniu, zmierzające do realizacji celu dyrektywy, jakim jest wyeliminowanie skutków wszystkich zobowiązań powstałych i wykonanych na podstawie warunku, którego nieuczciwy charakter został stwierdzony wobec konsumenta?

${ }^{11} \mathrm{~W}$ tej sprawie zadano następujące pytania: 1) Czy przepisy dyrektywy Rady 93/13/EWG w sprawie nieuczciwych warunków w umowach konsumenckich, w szczególności motywy 12, 21 i 23 , art. 2 lit. b), art. 6 ust. 1, art. 7 ust. 2 i art. 8, zgodnie z zasadą autonomii proceduralnej oraz równocześnie zasadami równoważności i skuteczności, zezwalają na obowiązywanie instrumentów prawnych obejmujących zwykłe roszczenie, niepodlegające przedawnieniu, mające na celu stwierdzenie nieuczciwego charakteru niektórych warunków ujętych w umowach zawieranych z konsumentami, oraz zwykłe roszczenie o charakterze osobistym i majątkowym, podlegające przedawnieniu, zmierzające do realizacji celu dyrektywy jakim jest wyeliminowanie skutków wszystkich zobowiązań powstałych i wykonanych na podstawie warunku, którego nieuczciwy charakter został stwierdzony wobec konsumenta?; 2) Na wypadek udzielenia odpowiedzi twierdzącej na pytanie pierwsze, czy te same przepisy stoją na przeszkodzie wykładni wynikającej z zastosowania zasady pewności stosunków cywilnoprawnych, zgodnie z którą obiektywna chwila, w której konsument wiedział lub powinien był wiedzieć o istnieniu nieuczciwego warunku, to chwila wygaśnięcia umowy kredytu, w ramach której przysługiwał mu status konsumenta? 
ocenie zagadnienie to jest tymczasem najmniej problematyczne, biorąc pod uwagę zamierzone cele dyrektywy 93/13/EWG, w tym założenia co do pełnej skuteczności ochrony przyznanej na jej gruncie konsumentom.

Wedle Trybunału ochrona konsumenta nie jest bezwarunkowa. Między innymi orzekł w związku z tym, że prawo Unii Europejskiej nie nakłada na sąd krajowy obowiązku wyłączenia stosowania krajowych przepisów proceduralnych przyznających w szczególności powagę rzeczy osądzonej orzeczeniu, nawet jeżeli pozwoliłoby to na usunięcie naruszenia przepisu zawartego $\mathrm{w}$ dyrektywie 93/13/EWG, niezależnie od jego charakteru [zob. wyrok z 6 października 2009 r., C-40/08 Asturcom Telecomunicaciones, pkt 37]. Ponadto Trybunał uznał, że ustalanie rozsąanych terminów do wniesienia środków zaskarżenia pod rygorem prekluzji w interesie pewności prawa jest zgodne z prawem Unii [zob. wyrok z 6 października 2009 r., C-40/08 Asturcom Telecomunicaciones, pkt 41].

Niemniej, zaakcentował jednocześnie, że należy odróżnić stosowanie zasady proceduralnej, takiej jak rozsądny termin przedawnienia, od ograniczenia w czasie skutków interpretacji jednego z przepisów prawa Unii [zob. wyrok z 15 kwietnia 2010 r., C-542/08 Barth, pkt 30 i przytoczone tam orzecznictwo]. W tym zakresie przypomnieć trzeba, że tylko do Trybunału Sprawiedliwości UE, z uwagi na podstawowy wymóg jednolitego i powszechnego stosowania prawa unijnego, należy orzeczenie o ewentualnych ograniczeniach w czasie skutków wykładni, jaką nadał on takiemu przepisowi [zob. wyrok z 2 lutego 1988 r., 309/85 Barra i in., pkt 13]. Zasadniczo więc dokonaną przez TSUE wykładnię regulacji prawnej Unii sądy krajowe powinny stosować również do stosunków prawnych powstałych i ustanowionych przed wydaniem przez Trybunał wyroku. $\mathrm{Z}$ racji tego, w wyroku z 21 grudnia 2016 r., sprawy połączone C-154/15, C-307/15 i C-308/15 $5^{12}$, TSUE jednoznacznie i wyraźnie wywiódł, że orzecznictwo krajowe dotyczące ograni-

${ }^{12}$ Trzeba mieć na uwadze, że w ww. sprawach połączonych pierwszorzędne znaczenie miał wyrok Sądu Najwyższego w Hiszpanii nr 241/2013 z 9 maja 2013 r. Rozpatrując powództwo zbiorowe o nakazanie zaprzestania wniesione przez stowarzyszenie ochrony konsumentów przeciwko kilku instytucjom kredytowym, Tribunal Supremo (sąd najwyższy) w wyroku nr 241/2013 z dnia 9 maja 2013 r. (zwanym dalej „wyrokiem z dnia 9 maja 2013 r.”), po stwierdzeniu nieuczciwego charakteru warunków przewidujących minimalną stopę, poniżej której nie mogła spaść stopa odsetek zmiennych (zwanych dalej „klauzulami dolnego progu”), znajdujących się w ogólnych warunkach umów kredytu hipotecznego zawieranych z konsumentami, stwierdził nieważność wspomnianych warunków. Tribunal Supremo (sąd najwyższy) stwierdził jednak, że odnośne umowy kredytu hipotecznego mogły nadal istnieć, i dodatkowo ograniczył moc wsteczną skutków stwierdzenia nieważności klauzul „dolnego progu”. Mianowicie, na podstawie zasady pewności prawa, ograniczył skutki swojego wyroku, które powstawały od dnia jego publikacji, postanawiając, że stwierdzenie nieważności rozpatrywanych klauzul „dolnego progu” nie miało wpływu na sytuacje ostatecznie rozstrzygnięte orzeczeniami sądowymi mającymi powagę rzeczy osądzonej ani na płatności, które zostały dokonane przed dniem 9 maja 2013 r., w ten sposób, że tylko kwoty, które zostały nienależnie zapłacone na podstawie tych klauzul po tej dacie, musiały zostać zwrócone. 
czenia w czasie skutków prawnych wynikających na podstawie art. 6 ust. 1 dyrektywy 93/13/EWG ze stwierdzenia nieuczciwego charakteru warunku umownego, pozwala jedynie na zapewnienie ograniczonej ochrony konsumentów. Taka ochrona okazuje się niekompletna i niewystarczająca oraz nie stanowi ani adekwatnego, ani skutecznego środka służącego zaprzestaniu stosowania takiego rodzaju warunków, w przeciwieństwie do tego, co przewiduje art. 7 ust. 1 tej dyrektywy ${ }^{13}$. W tych okolicznościach Trybunał Sprawiedliwości UE ostatecznie przesądził, że art. 6 ust. 1 dyrektywy 93/13 należy interpretować $w$ ten sposób, że sprzeciwia się on orzecznictwu krajowemu ograniczającemu w czasie skutki restytucyjne związane ze stwierdzeniem nieuczciwego charakteru $-w$ rozumieniu art. 3 ust. 1 tej dyrektywy - warunku znajdujacego się w umowie zawartej z konsumentem przez przedsiębiorce jedynie do kwot nienależie zaplaconych na podstawie takiego warunku po ogłoszeniu orzeczenia, w którym sąd stwierdził ów nieuczciwy charakter [sprawy połączone C-154/15, C-307/15 i C-308/15]. Szczególny akcent należy postawić tu więc na „skutek restytucyjny”, który obejmuje sytuację prawną i faktyczną konsumenta (założenie o zachowaniu synergii między sytuacją prawną i faktyczną konsumenta) i w związku z tym nie może sprowadzać się tylko do samego unieważnienia danej czynności prawnej lub jej postanowienia. Wówczas bowiem nie doszłoby do przywrócenia ekonomicznej równowagi praw i obowiązków konsumenta z przedsiębiorcą. Innymi słowy, skutek restytucyjny dotyczy zarówno przywrócenia dawnego stanu prawnego, jak i stanu materialnego kontrahentów, tak jak gdyby nigdy nie związali się oni postanowieniem lub umową, będących podstawą do nałożenia na nich pewnych obowiązków niematerialnych i/lub pieniężnych.

Na gruncie powyższego zaznaczyć trzeba, że Trybunał Sprawiedliwości Unii Europejskiej wyraźnie sprzeciwił się ograniczeniom związanym z czasem (kwestia zakresu nie jest już kwestionowana ${ }^{14}$ ) obowiązywania orzeczenia sądu w przedmiocie nieuczciwego charakteru danego warunku umowy, z którym nierozerwalnie sprzężone pozostaje uprawnienie konsumenta do ochrony jego praw osobistych i majątkowych (np. do dochodzenia zwrotu środków wpłaconych na rzecz banku na podstawie niewiążącej, czyli nieistniejącej, klauzuli abuzywnej) [Zawiadomienie Komisji Europejskiej, pkt. 5.4.2.]. Z tego wynika, że w świetle celów dyrektywy 93/13/EWG pierwszorzędne znaczenie ma osiągnięcie wszystkich skutków (prawnych i ekonomicznych) stwierdzenia niewiążącego charakteru nieuczciwych warunków umownych. W tym stanie rzeczy, sądowe uznanie warunków umowy za nieuczciwe nie może też zostać ograniczone co do rodzaju skutku. Co ważne - i czego nie można weryfikować w oderwaniu od powyższego - to, że konsumenci mogą zawsze skorzystać z tej ochrony w odniesieniu do roszczeń sprzedawców lub dostawców, które związane są z nieuczciwymi warunkami

${ }^{13}$ Zob. podobnie wyrok z 14 marca 2013 r., C-415/11 Aziz, pkt 60.

${ }^{14}$ Niegdyś była na gruncie abstrakcyjnej kontroli wzorów umów. 
umownymi, podnosząc zarzut nieuczciwości samodzielnie albo w drodze kontroli urzędowej, ponieważ uprawnienie to nie ulega przedawnieniu. Sąd krajowy nie może wobec tego - na przykład - wykluczyć roszczeń restytucyjnych w ogóle albo $\mathrm{w}$ odniesieniu do czasu poprzedzającego takie stwierdzenie (w całości lub części). W konsekwencji tego, ustalenie w postępowaniu sądowym nieuczciwości warunku umownego zawsze będzie miało charakter i skutek ex tunc wobec uprawnień majątkowych oraz niemajątkowych i to bez względu na to, czy rozstrzygnięcie w tym przedmiocie jest konstytutywne czy deklaratoryjne. Niemniej, w świetle polskiego porządku prawnego zasadniczo charakter orzeczenia sądowego ma znaczenie dla rozpoczęcia biegu terminu przedawnienia dla roszczenia o zapłatę świadczenia nienależnego. W mojej ocenie rozróżnienie to nie ma jednak wpływu na zwrot świadczeń uregulowanych na podstawie nieuczciwych warunków umownych właśnie ze względu na założoną przez prawodawcę unijnego skuteczną, czyli kompleksową - odnoszącą się do sfery materialnej i osobistej, ochronę prawną konsumenta.

\section{TRADYCYJNY PODZIAL ORZECZEŃ NA KONSTYTUTYWNE ORAZ DEKLARATORYJNE (BEZ ZNACZENIA DLA SYTUACJI TZW. „FRANKOWICZÓW”) - KRÓTKI ZARYS}

Kwestia tego, jaki skutek: ex tunc czy ex nunc ma określone orzeczenie, związana jest nie z samym podziałem orzeczeń na konstytutywne oraz deklaratoryjne, ale zależy od właściwości stosunku materialnoprawnego oraz stanu faktycznego konkretnej sprawy. Każdy akt stosowania prawa odnosi się do określonego stanu faktycznego i w związku z tym jego skutki prawne mogą być powiązane w czasie z zaistnieniem tego stanu faktycznego. Należy zatem uznać, że akt kreujący określone prawa i obowiązki, pozostaje zawsze w związku z zaistnieniem przesłanek faktycznych, stanowiących podstawę powstania określonych skutków prawnych. W takiej sytuacji konstytutywna decyzja może działać zarówno z mocą na przyszłość, jak i z mocą wsteczną.

Nie wchodząc w pogłębione rozważania na temat istoty poniższego podziału, ani jego funkcji i znaczenia praktycznego, odnotować trzeba, że charakter deklaratoryjny mają orzeczenia ustalające $\mathrm{w}$ tym sensie, iż potwierdzają istnienie lub nieistnienie prawa lub stosunku prawnego, nie wprowadzając zmian w zakresie tego stosunku. Różnica między orzeczeniem deklaratoryjnym a orzeczeniem ustalającym sprowadza się do tego, że w przypadku orzeczenia deklaratoryjnego sąd stwierdza wymagalny obowiązek świadczenia, zobowiązując do jego spełniania, w przypadku zaś orzeczenia ustalającego sąd nie zobowiązuje do świadczenia, lecz jedynie stwierdza istnienie lub nieistnienie prawa lub stosunku prawnego. Orzeczenia deklaratoryjne i ustalające nie zmieniają prawa lub stosunku prawnego w sferze prawa materialnego, lecz jedynie potwierdzają stan prawny. 
Odrębną kategorię per se stanowią orzeczenia prawokształtujące ${ }^{15}$. Orzeczenie prawokształtujące kształtuje sferę prawa lub stosunku prawnego, powodując jego powstanie, zmianę lub ustanie. Orzeczenie prawokształtujące nie potwierdza stanu istniejącego w obszarze prawa materialnego, lecz dokonuje jego zmiany. Podstawa do dokonania zmiany musi być zakotwiczona w przepisach prawa materialnego. Istotą orzeczeń prawokształtujących jest to, że dopiero ich wydanie staje się konieczną przesłanką dla zaktualizowania się możliwości skutecznego dochodzenia stosownych roszczeń [Sąd Apelacyjny w Łodzi w wyroku z 27 października 2014 r., I ACa 802/14]. Nie chodzi przy tym o formalną możliwość dochodzenia określonego roszczenia, ale o możliwość rzeczywistą, zawsze ocenianą w realiach ustalonych w danej sprawie.

W przypadku, gdy wyrok sądu, przed którym zawisłaby sprawa $\mathrm{z}$ abuzywną klauzulą przeliczeniową, sprowadzałby się do zadeklarowania nieważności już istniejącej w umowie ${ }^{16}$ - wyrok deklaratoryjny, powstałby problem niekorzystnego dla kredytobiorcy przedawnienia roszczenia zwrotu udzielonego kredytu [Gontarski 2019]. Moment spełnienia świadczenia jest tu bowiem równoznaczny z momentem wymagalności zobowiązania zwrotu i od tego momentu biegłoby przedawnienie, czyli od wypłaty sumy kredytu (roszczenie banku) i każdej z rat jego spłaty (roszczenie kredytobiorcy). Inaczej jest w przypadku wzruszalności (condictio ob causam finitam - odpadnięcie podstawy prawnej świadczenia), gdzie przedawnienie zaczyna bieg od momentu unieważnienia umowy przez sąd - wyrok konstytutywny [Gontarski 2019].

W doktrynie prawa krajowego przyjmuje się (choć nie powszechnie i jednolicie), że wyrok, w którym sąd uwzględnił powództwo o uznanie postanowienia wzorca umowy za niedozwolone jest wyrokiem konstytutywnym [Kadzik 2003: 51]. Uzasadnieniem tego jest założenie, wedle którego abuzywność może być rozpatrywana jedynie w odniesieniu do takiej klauzuli umownej, która istnieje w obrocie gospodarczym, a więc jest ważna, tyle że z określonych przyczyn nie wiąże konsumenta, ale wiąże w obrocie profesjonalnym (B2B) czy dwustronnie konsumenckim (C2C) [Sąd Apelacyjny w Warszawie w wyroku z 13 grudnia 2018 r., VI ACa 744/18]. Poza tym, art. $385^{1}$ k.c. nie może być traktowany jako przepis, który przewiduje inny skutek w rozumieniu art. 58 § 1 in fine k.c., w szczególności

\footnotetext{
${ }^{15}$ Choć w praktyce czasami trudno rozróżnić orzeczenie prawokształtujące od orzeczenia ustalającego, zwłaszcza, gdy stanowi ono prejudykat do dochodzenia żądania pieniężnego.

${ }^{16} \mathrm{~W}$ mojej ocenie wyrok, na mocy którego stwierdza się niewiążący charakter klauzuli abuzywnej nie ma charakteru deklaratoryjnego. Postanowienie wzorca umowy sprzeczne z ustawą nie może wywrzeć skutku prawnego (art. 58 § 1 k.c.) i nie może kształtować praw i obowiązków konsumenta oraz nie jest w stanie rażąco naruszyć jego interesów. Nie może też w konsekwencji podlegać ocenie z punktu widzenia zgodności z dobrymi obyczajami. Nie zawsze zresztą postanowienie wzorca umowy sprzeczne $\mathrm{z}$ ustawą musi być jednocześnie uznane za sprzeczne $\mathrm{z}$ dobrymi obyczajami, postanowienie zaś sprzeczne $\mathrm{z}$ dobrymi obyczajami $\mathrm{w}$ rozumieniu art. $385^{1} \S 1$ k.c. musi być zgodne z ustawą.
} 
ten, że na miejsce nieważnych postanowień czynności prawnej wchodzą odpowiednie przepisy ustawy [Sąd Najwyższy w uchwale z 13 stycznia 2011 r., III CZP 119/10].

Od kwalifikacji rozstrzygnięcia sądowego ${ }^{17}$ ważniejsze jest jednak to, że według pożądanej (właściwej) wykładni art. $385^{1} \S 1$ k.c. i leżących u jego podstaw postanowień dyrektywy Rady 93/13 EWG (art. 6 ust. 1), tzW. incydentalna kontrola postanowień umowy z udziałem konsumenta odbywa się z urzędu w każdej sprawie $^{18}$, w której dochodzone jest roszczenie wywodzone $\mathrm{z}$ takiej umowy i nie wymaga wydania odrębnego orzeczenia o abuzywności postanowienia umowy. Kontrola ta zakłada jedynie dokonanie oceny w tym względzie, stanowiącej przesłankę rozstrzygnięcia o dochodzonym roszczeniu. Słusznie wobec tego przyjął Sąd Najwyższy w uchwale z 6 kwietnia 2018 r., III CZP 114/17, że uznanie postanowienia za abuzywne przez organ stosujacy prawo nie ma zatem charakteru rozstrzygnięcia konstytutywnego, lecz wytacznie stwierdzenia niedozwolonego charakteru ocenianego postanowienia ze skutkiem wynikajacym z ustawy. Skutkiem tym jest bezskuteczność niedozwolonego postanowienia, czyli brak mocy wiążacej od samego początku, z tym jednak zastrzeżeniem, że wedtug utrwalajacego się stanowiska Trybunału Sprawiedliwości Unii Europejskiej klauzuli abuzywnej nie stosuje się, ,chyba że konsument temu się sprzeciwi”, działając świadomie $i$ wyraźnie w sposób wolny (zob. wyrok Sądu Najwyższego z dnia 14 lipca

${ }^{17}$ Tym bardziej, że rozstrzygnięcie wydane na mocy art. $385^{1}$ k.c. de facto zawiera zarówno elementy charakterystyczne dla wyroku deklaratoryjnego (nieważność ex lege, choć nie ma ona charakteru bezwzględnego - np. nie obejmuje sytuacji, gdy stronami umowy są przedsiębiorcy), jak i elementy wyroku konstytutywnego (aktualizacja roszczeń restytucyjnych; ostateczne orzeczenie zależy od woli konsumenta i jego interesów; w szczególnych sytuacjach nieuczciwe postanowienie może być zastąpione przepisem dyspozytywnym).

18 Aby zrekompensować strukturalnie słabszą pozycję konsumentów, którzy mogą nie być świadomi przysługujących im praw, a tym samym nie powołać się na nieuczciwy charakter warunków umowy, sądy krajowe - jako bezstronne organy - pełnią aktywną rolę w postępowaniach dotyczących nieuczciwych warunków umownych. Od chwili wydania swojego orzeczenia z dnia 4 czerwca 2009 r. (por. sprawę C-243/08 Pannon GSM, sentencja wyroku. Zgodnie z wcześniejszym orzecznictwem, począwszy od postanowień orzeczenia w sprawach połączonych C-240/98-244/98 Océano Grupo Editorial, które zostały następnie potwierdzone w szeregu kolejnych orzeczeń, Trybunał nałożył na sądy krajowe obowiązek dysponowania uprawnieniami do analizowania nieuczciwych warunków umownych $\mathrm{z}$ własnej inicjatywy. Ta zmiana w orzecznictwie Trybunału została wyjaśniona w sprawie C-168/15 Milena Tomášová, pkt 28-31). Trybunał pozostaje na stanowisku, że sądy krajowe są zobowiązane do oceniania nieuczciwych warunków umownych $\mathrm{z}$ własnej inicjatywy (z urzędu), tj. nawet w przypadku, gdy konsument nie powołał się na nieuczciwy charakter warunków umowy. Celem kontroli z urzędu jest zapewnienie osiągnięcia rezultatu wskazanego $\mathrm{w}$ art. 6 ust. $1 \mathrm{w}$ indywidualnych przypadkach oraz wniesienie wkładu w realizację celu wyznaczonego w art. 7, ponieważ taka kontrola może pełnić funkcję środka zniechęcającego do stosowania ogólnie rozumianych nieuczciwych warunków umownych. Obowiązek przeprowadzania kontroli $\mathrm{z}$ urzędu ma zastosowanie tym bardziej w przypadku, gdy konsument zasadniczo zakwestionuje ważność lub uczciwość umowy, nie powołując się jednak na konkretnie przepisy prawne dotyczące nieuczciwych warunków umownych. 
2017 r., II CSK 803/16, OSNC 2018, nr 7-8 poz. 79, oraz wyrok Trybunatu Sprawiedliwości Unii Europejskiej z dnia 20 września 2017 r., C-186/16, R. P. Andriciuc przeciwko Banca Româneascã). W konsekwencji tego nie ma potrzeby rozważać zagadnienia, czy sankcję tę należy kwalifikować jako nieważność bezwzględną czy jako inny rodzaj bezskuteczności ex lege i ab initio. Wystarczy bowiem stwierdzenie, że niedozwolone postanowienie umowy w rozumieniu art. $385^{1} \S 1$ k.c. jest $\mathrm{z}$ mocy prawa pozbawione mocy wiążącej od samego początku i każdy organ orzekający w sprawie dotyczącej roszczenia $\mathrm{z}$ umowy $\mathrm{z}$ udziałem konsumenta jest obowiązany z urzędu to uwzględnić, chyba że konsument temu się sprzeciwi w sposób niewymuszony i jednoznaczny.

\section{ISTOTA I FUNKCJA MATERIALNYCH TERMINÓW PRZEDAWNIENIA - ZARYS PROBLEMATYKI}

Przedawnienie roszczeń majątkowych jest jedną z postaci „dawności”. Pod pojęciem dawności rozumieć należy zbiór instytucji prawa cywilnego łączących skutki prawne (zmianę, powstanie lub ustanie stosunku prawnego) z upływem czasu; poza przedawnieniem postaciami dawności są także terminy zawite (prekluzja), zasiedzenie i przemilczenie [Sąd Najwyższy (7) w uchwale z 26 listopada 2014 r., III CZP 45/14]. Terminy przedawnienia oraz terminy zawite należą do terminów prawa materialnego i różnią się od terminów procesowych (wynikających z ustawy lub ustanawianych przez sąd). Odróżniają się od terminów materialnoprawnych wywoływanymi skutkami [Fras i Habdas (red.), 2019, art. 117 k.c.]. Mianowicie nie powodują one ani wygaśnięcia ${ }^{19}$, ani utrudnienia realizacji uprawnienia, ale wyznaczają czasowe granice podjęcia przez uczestników postępowania skutecznych czynności procesowych oraz czynności sądu.

Przedawnieniu podlegają wyłącznie cywilnoprawne roszczenia majątkowe, czyli nakierowane na realizację interesu ekonomicznego osoby uprawnionej. Roszczenie to nic innego jak uprawnienie polegające na możliwości domagania się od indywidualnie określonej osoby (lub grupy indywidualnie określonych osób) jakiegoś zachowania się (działania bądź zaniechania). Istnienie roszczenia jest więc konsekwencją nałożenia przez normę prawną na konkretnego adresata lub grupę konkretnych adresatów obowiązku jakiegoś postępowania względem innej osoby. Ponieważ przedawniają się tylko tzw. roszczenia materialnoprawne, to art. $117 \S 1$

${ }^{19}$ Dalsze istnienie przedawnionego roszczenia odróżnia przedawnienie od prekluzji (terminów zawitych), która polega na tym, że roszczenie niedochodzone w ciągu określonego terminu wygasa $\mathrm{z}$ chwilą upływu terminu, co sąd uwzględnia zawsze $\mathrm{z}$ urzędu. Skutek taki jest określony w normie prawnej (np. w art. 59 k.c., art. $344 \S 2$ k.c., art. $563 \S 1$ k.c. i art. 568 k.c.). Z tego też względu roszczenie, które uległo prekluzji, nie może już być skutecznie potrącone. 
k.c. nie dotyczy tzw. roszczenia procesowego ${ }^{20}$, które jest skierowanym do sądu, uzasadnionym okolicznościami faktycznymi, żądaniem udzielenia ochrony prawnej w drodze rozpoznania sprawy i wydania wyroku określonej treści.

Cel i funkcja instytucji przedawnienia sprowadzają się do usunięcia stanu niepewności prawnej w sytuacji, gdy uprawniony przez bardzo długi czas nie wykonuje swoich praw podmiotowych, nie realizuje przysługujących mu roszczeń. Przedawnienie pełni zatem funkcję stabilizacyjną porządku prawnego - zapewnia ochronę dłużnikowi, którego położenie prawne mogłoby się pogarszać wraz $\mathrm{z}$ upływem czasu, ponieważ trudniej byłoby mu przedstawić dowody, z których wynika, że albo nigdy nie był zobowiązany, albo jego obowiązek wygasł już wcześniej wskutek jego wykonania. Uzasadnieniem prawnym przedawnienia jest także bezpieczeństwo prawne dłużnika (zob. art. 2 Konstytucji RP) rozumiane jako pewność co do własnej sytuacji prawnej. Sprzeczne z nim byłoby pozostawanie zobowiązanego w długotrwałej niepewności co do zachowania uprawnionego. Po upływie pewnego czasu sytuacja prawna dłużnika ulega wyjaśnieniu. Zyskuje on pewność, że uprawniony nie będzie dochodził od niego spełnienia świadczenia [Fras i Habdas (red.), 2019, art. 117 k.c].

Sąd Okręgowy w Warszawie w wyroku z 31 maja 2019 r., XXV C 1567/17 uznał, że do początku biegu terminu przedawnienia roszczeń wynikających ze stosunków kredytowych nie dochodzi do momentu, w którym konsument nie zakwestionuje skuteczności bądź ważności postanowień uprzednio wykonywanej umowy $^{21}$. Dopiero wówczas powstaje stan, w którym wierzyciel może podjąć czynności zmierzające do postawienia ich $\mathrm{w}$ stan wymagalności w rozumieniu art. $120 \S 1$ k.c. Należy przytoczyć tu również pogląd Sądu Najwyższego, wyrażony w wyroku z 29 kwietnia 2009 r. [II CSK 625/08], w którym Sąd ten przyjął, że przy ocenie przedawnienia roszczeń z tytułu zwrotu świadczenia wzajemnego wynikajacego z umowy uznanej za nieważna należy wziać pod uwage zachowanie stron zmierzające do wykonania zobowiązań wzajemnych i dopóki ten stan respektuja, trudno mówić o wymagalności roszczeń. W mojej jednak ocenie analiza terminów przedawnienia w kontekście skutków restytucyjnych tzw. „frankowiczów" związanych ze stwierdzeniem bezskuteczności nieuczciwego warunku umownego lub unieważnienia umowy kredytu w całości bądź części jest bezprzedmiotowa $z$ uwagi na cele zamierzone w dyrektywie 93/13/EWG. Zwłaszcza, że powództwo oparte na art. $385^{1}$ k.c. nie może ulec przedawnieniu, a jego uwzględnienie każdorazowo działa ex tunc wobec sytuacji prawnej i materialnej konsumenta.

${ }^{20}$ Wydaje się tymczasem, że o prekluzji/przedawnieniu TSUE rozważał właśnie w kontekście roszczenia procesowego, a nie materialnoprawnego, co ma kluczowe znaczenie dla właściwego zrozumienia badanej w tym artykule problematyki.

${ }^{21}$ Przy oczywistym założeniu, że bank nie ma interesu prawnego w zakwestionowaniu warunków umownych, które samodzielnie zredagował i narzucił swym klientom. 


\section{PODSUMOWANIE}

Niewiążący charakter nieuczciwych warunków umownych w rozumieniu art. 6 ust. 1 jest przepisem bezwzględnie obowiązującym, dzięki któremu w dyrektywie 93/13/EWG zmierza się do usunięcia asymetrii praw i obowiązków konsumenta oraz zapewnienia równowagi rzeczywistej (w sferze uprawnień i obowiązków, co odpowiednio dotyczy aspektu prawnego i ekonomicznego) między stronami umowy. Niewiążący charakter nieuczciwych warunków umownych wynika więc bezpośrednio $\mathrm{z}$ ww. aktu prawa UE i nie wymaga uprzedniego wydania stosownego orzeczenia przez sąd lub inny uprawniony organ. Tego rodzaju stwierdzenia zapewniają jednak pewność prawa w odniesieniu do (nie)uczciwego charakteru danego warunku umowy, w szczególności w przypadkach, w których mogą istnieć odmienne zdania co do jego nieuczciwego charakteru. Zatem niewiążący charakter nie może zależeć od tego, czy, kiedy i w jaki sposób konsument podniósł kwestię nieuczciwego charakteru danego warunku umowy lub go zaskarżył.

Efektem niewiążącego charakteru nieuczciwych warunków umownych jest prawo konsumentów do otrzymania zwrotu płatności dokonanych na podstawie nieuczciwych warunków umownych. Jedynie przepisy dotyczące pewności prawa mogą zredukować taki (materialny/ekonomiczny) skutek restytucyjny, w szczególności przepisy dotyczące powagi rzeczy osądzonej i rozsądnych terminów przedawnienia. Jednocześnie państwa członkowskie, w tym prawodawcy i sądy krajowe, nie mogą ograniczać w czasie skutków stwierdzenia nieuczciwego charakteru danego warunku, a tym samym - na przykład - wykluczyć możliwości dochodzenia roszczeń restytucyjnych w całości lub części (m.in. w odniesieniu do czasu poprzedzającego takie stwierdzenie). Tego rodzaju ograniczenie należy więc wyraźnie odróżnić od materialnych terminów przedawnienia przewidzianych w prawie krajowym, które będą miały zastosowanie wyłącznie do roszczeń pieniężnych dochodzonych po prawomocnym uznaniu warunku umownego za nieuczciwy. Aczkolwiek właściwsze byłoby powoływanie się w tym względzie na termin zawity (prekluzyjny), gdyby takowy istniał w Polsce. Być może obecna sytuacja skłoni ustawodawcę do uregulowania tej kwestii, zwłaszcza, że budzi ona sporo kontrowersji.

Przyjąć należy, że tzw. „frankowiczom” w sytuacji wzruszenia klauzul abuzywnych zawartych w umowach kredytów denominowanych w CHF lub indeksowanych do CHF przysługuje zwrot tego, co nienależnie świadczyli na podstawie tych warunków na rzecz banków w całym okresie kredytowania. Tylko w taki sposób możliwe jest bowiem przywrócenie rzeczywistej równowagi kontraktowej oraz wywarcie efektu odstraszającego wobec przedsiębiorcy. Wobec tego charakter orzeczenia uznającego klauzule umowne za abuzywne nie ma żadnego wpływu na możliwość dochodzenia roszczeń majątkowych na tym gruncie. Nienależność 
świadczeń to efekt wyeliminowania $\mathrm{z}$ obrotu prawnego podstawy do ich regulowania (skutek prawny) w drodze prawomocnego orzeczenia sądowego, choć przyczyna tego wynika bezpośrednio z przepisów prawa (dyrektywy 93/13/EWG w zw. z art. $385^{1}$ k.c.). Warunek umowny uznany za nieuczciwy należy bowiem co do zasady uznać za nigdy nieistniejący, czyli taki, który od początku nie wywoływał skutków wobec konsumenta, ergo - tzw. „frankowicz” nie był zobowiązany na jego podstawie do spłaty rat odsetkowych oraz kapitałowo-odsetkowych, a także pokrycia pozostałych kosztów kredytu (prowizji, ubezpieczeń, opłat za prowadzenie rachunku bankowego i wydanie karty kredytowej, etc.).

W cytowanej uchwale z 6 kwietnia 2018 r. Sąd Najwyższy zważył, że jeżeli powstanie dochodzonego roszczenia (pieniężnego) zależy od tego, czy określone postanowienia umowy z udziałem konsumenta, z której dochodzone roszczenie jest wywodzone, są postanowieniami niedozwolonymi, przesłanka ta jest spełniona już z chwilą zawarcia tej umowy i podlega uwzględnieniu przez sąd $\mathrm{z}$ urzędu, tj. bez konieczności nie tylko wydania konstytutywnego orzeczenia o abuzywności klauzuli, ale i powołania się na abuzywność klauzuli. Tym samym Sąd Najwyższy przesądził, że po pierwsze - roszczenie wywiedzione w oparciu o art. $385^{1}$ k.c. ma charakter prawokształtujący (co jest argumentem dla wszystkich tych, którzy jednak dopuszczają możliwość podniesienia zarzutu przedawnienia roszczenia o zwrot świadczenia pieniężnego spłaconego na podstawie nieuczciwego warunku umownego w trakcie postępowania sądowego opierającego się na argumentacji o abuzywności klauzul umownych), a po drugie - ważniejsze - że możliwość jego dochodzenia nie zależy od uznania postanowienia wzorca umownego za nieuczciwe, ew. unieważnienia na tej podstawie w całości bądź części umowy kredytu. Uprawnienie to przysługuje tzw. „frankowiczom” z mocy prawa UE i nie może być w żaden sposób (także co do czasu) ograniczone przepisami kodeksu cywilnego, $w$ tym przede wszystkim instytucją przedawnienia.

Zarzut przedawnienia będzie zasadny jedynie w takiej sytuacji, gdy przy rozstrzyganiu przez sąd o unieważnieniu klauzuli bądź umowy w całości lub części żaden z kontrahentów nie podejmie działań zmierzających do jednoczesnego wyegzekwowania nienależnego świadczenia od dłużnika. Albo też, gdy abuzywność klauzuli zostanie stwierdzona $\mathrm{w}$ ramach abstrakcyjnej kontroli sądowej. Termin przedawnia (przeważnie będzie to termin 10-letni dla konsumenta i 3-letni dla banku) może bowiem ograniczyć w czasie skuteczność dochodzenia roszczenia pieniężnego, którego zwrot co do zasady - w obu ww. przypadkach - należy się konsumentowi. Właściwsze byłoby jednak wprowadzenie przez ustawodawcę regulacji obejmującej prekluzję co do wytoczenia tego rodzaju żądania w tym zakresie. Dopóki jednak istnieje luka w tym obszarze, dopóty sądy krajowe powinny powstrzymać się od uwzględniania $\mathrm{w}$ trakcie procesów o zapłatę $\mathrm{z}$ tytułu unieważnienia umowy kredytu tzw. „frankowego” w całości bądź części lub z tytułu 
nadpłaty w spłacie kredytu instytucji przedawnienia roszczenia. Zwrócenie świadczenia nienależnego w niepełnej wysokości stanowi bowiem naruszenie obowiązującego prawa UE, co w mojej ocenie kwalifikować należy jako przesłankę do pociągnięcia Polski do odpowiedzialności za jego nieprzestrzeganie.

\section{BIBLIOGRAFIA}

Dyrektywa Rady 93/13/EWG z 5 kwietnia 1993 r. w sprawie nieuczciwych warunków w umowach konsumenckich, Dz.U. UE.L. 1993.95.29 z 21 kwietnia 1993 r.

Fras M., Habdas M. (red.), 2019, Kodeks cywilny. Komentarz, publ. LEX/el., art. 117 k.c.

Gontarski W., 2019, Nieważność bezwzględna i inne konsekwencje prawne nieuczciwych klauzul walutowych. Glosa do wyroku TS z dnia 3 października 2019 r., C-260/18, publ. LEX/el.

Grebieniow A., Osajda K., 2019, Kredyty walutowe. Węzłowe Zagadnienia, „Studia i Analizy Sądu Najwyższego. Materiały Naukowe”, t. VII, Warszawa.

Jabłoński M., Koźmiński K., 2018, Bankowe kredyty waloryzowane do kursu walut obcych w orzecznictwie sadowym, Warszawa.

Kadzik A., 2003, Postępowanie w sprawach o uznanie postanowień wzorca umowy za niedozwolone (abstrakcyjna kontrola wzorców umownych), „Radca Prawny”, nr 4.

Postanowienie Sądu Okręgowego w Gdańsku z 30 grudnia 2019 r., sygn. akt XV C 458/18, niepubl.

Uchwała Sądu Najwyższego (7) z 26 listopada 2014 r., sygn. akt III CZP 45/14, OSNC 2015, nr 5, poz. 54.

Uchwała Sądu Najwyższego z 13 stycznia 2011 r., sygn. akt III CZP 119/10, OSNC 2011, nr 9, poz. 95.

Uchwała Sądu Najwyższego z 6 kwietnia 2018 r., sygn. akt III CZP 114/17, OSNC 2019, nr 3, poz. 26.

Ustawa z 2 marca 2000 r. o ochronie niektórych praw konsumentów oraz o odpowiedzialności za szkodę wyrządzoną przez produkt niebezpieczny, Dz.U. 2012, poz. 1225 ze zm.

Ustawa z 23 kwietnia 1964 r. Kodeks cywilny, Dz.U. 2019, poz. 1145 ze zm.

Wniosek o wydanie orzeczenia w trybie prejudycjalnym złożony przez Tribunalul Specializat Mureş (Rumunia) 7 listopada 2018 r. - SC Raiffeisen Bank SA/JB, Dz.U. UE.C. 2019.54.4/2 z 11 lutego 2019 r.

Wniosek o wydanie orzeczenia w trybie prejudycjalnym złożony przez Tribunalul Specializat Mureș (Rumunia) 7 listopada 2018 r. - BRD Groupe Société Générale SA/KC, Dz.U. UE.C. 2019.54.5/1 z 11 lutego 2019 r.

Wyrok Sądu Apelacyjnego w Łodzi z 27 października 2014 r., sygn. akt I ACa 802/14, LEX nr 1554765.

Wyrok Sądu Apelacyjnego w Warszawie z 13 grudnia 2018 r., sygn. akt VI ACa 744/18, LEX nr 2668906.

Wyrok Sądu Najwyższego z dnia 29 kwietnia 2009 r., sygn. akt II CSK 625/08.

Wyrok Sądu Najwyższego z dnia 14 lipca 2017 r., sygn. akt II CSK 803/16, OSNC 2018.

Wyrok Sądu Najwyższego z 29 października 2019 r., sygn. akt IV CSK 309/18, LEX nr 2732285.

Wyrok Sądu Najwyższego z 3 lutego 2006 r., sygn. akt I CK 297/05, „Biuletyn Sądu Najwyższego” 2006, nr 5, s. 12.

Wyrok Sądu Okręgowego w Warszawie z 15 marca 2019 r., sygn. akt XXV C 2/19, LEX nr 2675927.

Wyrok Sądu Okręgowego w Warszawie z 31 maja 2019 r., sygn. akt XXV C 1567/17, LEX nr 2697360.

Wyrok TSUE z 10 lipca 1997 r., C-261/95 Palmisani, http://eur-lex.europa.eu/ - Judgment of the Court of 10 July 1997, Case C-261/95.

Wyrok TSUE z 12 lutego 2008 r., C-2/06 Kempter, ZOTSiS 2008, nr 2, poz. I-411.

Wyrok TSUE z 14 marca 2013 r., C-415/11 Aziz, EU:C:2013:164. 
Wyrok TSUE z 15 kwietnia 2010 r., C-542/08 Barth, EU:C:2010:193.

Wyrok TSUE z 16 grudnia 1976 r., 33/76 Rewe-Zentralfinanz i Rewe-Zentral, http://eur-lex.europa.eu/ - Judgment of the Court of 16 December 1976, Case 33/76.

Wyrok TSUE z 17 lipca 2014 r., C-169/14 Sánchez Morcillo i Abril García, ECLI:EU:C:2014:2099.

Wyrok TSUE z 2 lutego 1988 r., 309/85 Barra $i$ in., EU:C:1988:42.

Wyrok TSUE z 21 grudnia 2016 r., C-154/15, C-307/15 i C-308/15 Gutiérrez Naranjo i in., ECLI:EU:C:2016:980.

Wyrok TSUE z 26 kwietnia 2012 r., C-472/10 Nemzeti Fogyasztóvédelmi Hatóság v. Invitel Távközlési Zrt, ECLI:EU:C:2012:242.

Wyrok TSUE z 26 stycznia 2017 r., C-421/14 Banco Primus, ECLI:EU:C:2017:60.

Wyrok TSUE z 27 czerwca 2000 r., C-240/98-244/98 Océano Grupo Editorial, http://curia.europa.eu/juris/liste.jsf?num $=\mathrm{C}-240 / 98$.

Wyrok TSUE z 28 lipca 2016 r., C-168/15 Milena Tomášová, ECLI:EU:C:2016:602.

Wyrok TSUE z 3 października 2019 r., C-260/18 Dziubak vs. Raiffeisen, http://eur-lex.europa.eu/.

Wyrok TSUE z 30 maja 2013 r., C-397/11 Erika Jörös v. Aegon Magyarország Hitel Zrt., ECLI:EU:C:2013:340.

Wyrok TSUE z 4 czerwca 2009 r., C-243/08 Pannon GSM, ZOTSiS 2009, nr 6A, poz. I-4713.

Wyrok TSUE z 6 października 2009 r., C-40/08 Asturcom Telecomunicaciones, EU:C:2009:615.

Wyrok TSUE z 7 sierpnia 2018 r., C-96/16 i C-94/17 Banco Santander Escobedo Cortés, http://eurlex.europa.eu/.

Wyrok TSUE z dnia 20 września 2017 r., C-186/16, R. P. Andriciuc przeciwko Banca Româneascã.

Zawiadomienie Komisji Europejskiej pt. Wytyczne dotyczace wykładni i stosowania dyrektywy Rady w sprawie nieuczciwych warunków w umowach konsumenckich, Dz.U. UE.C. 2019.323.4 z 27 września 2019 r.

\title{
LEGAL EFFECTIVENESS OF PROTECTING THOSE, WHO HAVE A MORTGAGE DENOMINATED IN SWISS FRANCS, IN THE CONTEXT OF LIMITATION PERIODS
}

\begin{abstract}
In Poland, there was no uniform court jurisprudence regarding the rationales and grounds for canceling the loan agreement, as well as the recognition of only certain contractual terms as unfair, consequently - also as to the application of limitation periods for the reimbursement of claims paid on the basis of abusive clause or invalid legal action. The situation was not changed by the EU Court of Justice judgment dated on the $3^{\text {rd }}$ of October 2019 (C-260/18 Dziubak vs. Raiffeisen). Meanwhile, it is desirable and necessary for national courts to start settling mortgage denominated in Swiss francs cases in the spirit of EU regulations, because it was within them that the idea of full legal protection of the consumer was adopted, in principle according to which the implementation of a claim for restitution cannot be dependent on the limitation period.

The purpose of the article is to answer the question: Does the restitution effect include - apart from the previous legal status - the restoration of the financial condition of contractors? Answering this question is necessary to determine whether judicial recognition of the terms of contract as unfair can be limited as to the type of the effect.

The above was the basis for the formulation of the following research thesis: determination of unfairness of contractual conditions in court proceedings will always have the character and
\end{abstract}


ex tunc effect towards property and non-property rights, regardless of whether the decision in this matter is constitutive or declaratory.

The presented matter determined the layout and content of the article, in which the issue of limitation periods (included in the preliminary rulings and the EU Court of Justice judgement) was discussed in many aspects, the division of judgments into constitutive and declarative ones, as well as the essence and function of substantive limitation periods were explained.

Keywords: prescription, restitution effect, constitutional/declaratory judgement, abusive clause, loan agreement annulment. 